\title{
Changes in snow cover occurrence and the atmospheric circulation impact in Poznań (Poland)
}

\author{
Katarzyna Szyga-Pluta ${ }^{1}$ (D)
}

Received: 14 January 2021 / Accepted: 17 November 2021 / Published online: 24 November 2021

(c) The Author(s) 2021

\begin{abstract}
The variability of occurrence of snow cover and the impact of atmospheric circulation on the snow cover occurrence in the period 1966/1967-2019/2020 in Poznań (Poland) have been examined. The implementation of the primary study objective covers the comprehensive analysis of the winter snow and thermal conditions using various indicators. This paper is based on daily data from the years 1966-2020 concerning the winter period. Winters in Poznań are highly variable and differentiated, considering the duration of particular seasons, number of days with snow cover, mean snow cover thickness, winter snowiness coefficient, or winter severity index. Negative trends concerning days with snow cover total snow cover depth winter snowiness coefficient and winter severity index in Poznań prove statistically significant. A higher probability of occurrence of snow cover was determined during cyclonic than anticyclonic circulation. The westerly and northerly types especially favoured the occurrence of days with snow cover. The increase of snow cover was associated with the northerly inflow mainly. Westerly types of circulation caused the decrease of snow cover predominantly.
\end{abstract}

Keywords Snow cover $\cdot$ Climate change $\cdot$ Poznań $\cdot$ Poland

\section{Introduction}

Snow cover is the most sensitive to changes in temperature and precipitation. It is therefore considered as a good indicator of climate change. Snow cover in Europe is primarily related to air temperature, whereas the effect of precipitation on snow cover is less obvious, mostly because the ratio of snowfall to precipitation is strongly determined by air temperature (Feng and Hu 2007). An increase in temperature results in a decrease in snow accumulation, and has reduced the period of occurrence of snow cover at moderate latitudes as well as at medium and low altitudes, and not in the coldest regions (e.g., Bulygina et al. 2009; Henderson and Leathers 2010; Brown and Robinson 2011; Ye and Lau 2017; Fontrodona Bach et al. 2018). The dependency of temperature on snow cover activates one of the strongest feedback effects related to climate changes, because due to its high albedo,

Katarzyna Szyga-Pluta

pluta@amu.edu.pl

1 Department of Meteorology and Climatology, Institute of Physical Geography and Environmental Planning, Adam Mickiewicz University, ul. Krygowskiego 10, 61-680 Poznań, Poland snow strongly modifies streams of energy between the surface and the atmosphere (Armstrong and Brun 2008). On the other hand, an increase in temperature results in reduction of snow cover. Further reduction of seasonal snow cover is expected in Europe according to climate projections (Adaptation in Europe 2013; Climate Change. Impacts and Vulnerability in Europe 2012). The projections suggest a decrease in the maximum snow cover thickness by approximately $-15 \%$ and approximately $-20 \%$, respectively, for RCP 4.5 and RCP 8.5 by the period 2021-2050, and doubling of those reductions by the period 2071-2100, irrespective of RCP, reaching up to $-40 \%$ according to RCP8.5 (Mezghani et al. 2017).

According to the classification of Paczos (1982), winters with little snow occur most frequently in Poland, and very high both temporal and spatial variability of snow cover is a characteristic phenomenon. This variability is manifested in several episodes of development and decline of snow cover during a single winter season, as well as high instability of the cover thickness and properties, determining its thermal isolation and hydrological role (Czarnecka 2011).

Snow cover's development and permanence are largely determined by thermal conditions, although considering the local and regional scale, wind speed is an important factor of deformation of snow cover. The presence of low pressure 
centres and advection of polar-marine air favour intensive snowfall in the lowland part of Poland (Czarnecka 2012). Duration and thickness of snow cover show considerable variability in time and space. It is an important climateforming factor (Nowosad and Bartoszek 2007). It plays an important role in the water and heat balance (Nowosad 1994). The thermal-humidity state of the atmosphere is visibly manifested in snow cover and cloudiness. They are also important stages of the process of water circulation in nature (Bednorz and Szyga-Pluta 2004).

The variability of snow cover thickness increased from year to year in the second half of the twentieth century, and showed spatial variability in Poland (Falarz 2004). The negative trend of snow cover found in the investigation of Falarz and Bednorz (2021) based on the data until 2018 is much more noticeable than in the results previously obtained in Poland. Many researchers, among others Niedźwiedź (1981), Bednorz (2002), Falarz (2007a), or Czarnecka (2012), point to the fact that the occurrence of snow cover largely depends on the current air circulation. According to the research by Piotrowski and Jędruszkiewicz (2013), thermal conditions of winters and snow cover in Poland have been and in the near future will be (2021-2050) closely related to atmospheric circulation.

The role of snow in the environment and its importance in the context of human activity has been discussed in many papers (Nowosad 1994; Bednorz 2001, 2009; Falarz 2007a; Franczak 2018). According to Franczak (2018), snow cover causes a change in the water and heat balance. Falarz (2007a) emphasizes the fact that for many areas of the economy such as among others agriculture, transport, or construction, it is important to designate the beginning and end of the potential period of occurrence of snow cover. Its occurrence frequently determines the beginning or end of different forms of human activity related to such areas. Nowosad (1994) points to the importance of snow for agriculture and consequences of its occurrence in urban areas.

Bearing the aforementioned in mind the variability of occurrence of snow cover in the period 1966/1967-2019/2020 in Poznań, a station representative of a region with low precipitation, including snowfall, has been examined. The primary study objective covers the comprehensive analysis of the winter snow and thermal conditions using various indicators. Moreover, the impact of atmospheric circulation on the snow cover occurrence has been determined.

\section{Materials and methods}

This paper is based on daily data from the years 1966-2020 concerning the winter period, i.e. months in which occurrence of snow cover was actually observed-in this case the period from October to May. The analysis was based on occurrence of snow cover and snow cover thickness on subsequent days in particular winter seasons. The used data were obtained from the collection of the Institute of Meteorology and Water Management-National Research Institute (IMGW-PIB) (dane.imgw.pl). Measurements were performed in the airport meteorological station Poznań-Ławica $\left(52^{\circ} 25^{\prime} 16^{\prime \prime} \mathrm{N} 16^{\circ} 49^{\prime} 35^{\prime \prime} \mathrm{E}\right)$. The data provided the basis for the calculation of the number of days with snow cover for particular seasons, mean snow cover depth, and determination of the maximum value. Variability measures were also calculated for these parameters, including standard deviation and the variability coefficient. Mean snow cover depth was calculated for days with snow cover, i.e. as the quotient of the sum of snow cover depth in a given season and number of days with snow cover. Snow cover depth in each season was also calculated by summing up snow cover thickness from all days with snow cover. The characteristics of winter snowiness were based on the winter snowiness coefficient by Paczos (1982) and calculated for the period 1966-2020:

$W_{s n}=0.0409 \cdot D_{s c}+0.0246 \cdot D_{s c 20}+0.00007 \cdot S_{s c t d}$

where:

$W_{s n}=$ winter snowiness coefficient.

$D_{s c}=$ number of days with snow cover with a depth of $\geq 1 \mathrm{~cm}$ in the period XII-III.

$D_{s c 20}=$ number of days with snow cover with a depth of $\geq 20 \mathrm{~cm}$ in the period XII-III.

$S_{\text {sctd }}=$ total snow cover depth in $\mathrm{cm}$ in the period XII-III.

The snowiness of winter was defined by the thickness and duration of the snow cover. The formation of snow cover depends on the air temperature. For this purpose, the winter severity index (Paczos 1985; Janasz 2000) was calculated based on daily air temperature data for the research period:

$$
\begin{aligned}
W_{\text {sev }}=(1-0.25 \cdot t) \cdot 0.8325 & +0.0144 \cdot d_{w}+0.0087 \cdot d_{f} \\
& +0.0045 \cdot d_{v f}-0.0026 \cdot S_{t}
\end{aligned}
$$

where:

$W_{\text {sev }}=$ winter severity index.

$t=$ mean winter season temperature.

$d_{w}=$ number of days with $t_{\mathrm{avr}}<0.0{ }^{\circ} \mathrm{C}$ in the period XII-III.

$d_{f}=$ number of frost days $\left(t_{\max }<0.0{ }^{\circ} \mathrm{C}\right)$ in the period XII-III.

$d_{v f}=$ number of very frost days $\left(t_{\max }<-10.0{ }^{\circ} \mathrm{C}\right)$ in the period XII-III.

$S_{t}=$ sum of the mean daily temperature $t_{\mathrm{avr}}<0.0^{\circ} \mathrm{C}$ in the period XII-III.

The abovementioned indicators (in the range of $(0-10)$ were developed adequately to the climatic conditions of 
Poland. The calculation of the winter snowiness coefficient and winter severity index omitted single cases of snow cover occurrence in months: April, May, and November.

The next step was examining the correlation of snowiness in winter seasons with their severity using the Pearson correlation coefficient.

On the basis of the long-term mean values of the snowiness and winter severity coefficients and their standard deviations, 3 groups of winters were distinguished, due to their severity (severe $\left(W_{\mathrm{sev}} \geq W_{\mathrm{sev}}+\sigma\right)$, moderately severe $\left(W_{\mathrm{sev}}-\sigma<W_{\mathrm{sev}}<W_{\mathrm{sev}}+\sigma\right)$, and mild winters $\left.\left(W_{\mathrm{sev}} \leq W_{\mathrm{sev}}-\sigma\right)\right)$ and due to snowiness (snowy winters $\left(W_{\mathrm{sn}} \geq W_{\mathrm{sn}}+\sigma\right)$, moderately snowy $\left(W_{\mathrm{sn}}-\sigma<W_{\mathrm{sn}}<W_{\mathrm{sn}}+\sigma\right)$, and low snowy winters $\left.\left(W_{\mathrm{sn}} \leq W_{\mathrm{sn}}-\sigma\right)\right)$, named winter thermal-snow types.

The presentation of the percent share of days with snow cover in the analysed seasons was based on the classification proposed by Chrzanowski (1988). He designated six types of snow cover based on ranges of its daily thickness (Table 1). In this paper, the classification by Chrzanowski was performed for winter seasons designated for subsequent years of the study period.

The duration of particular seasons was calculated as the number of days between the first and last day on which snow cover was observed. Moreover, the frequency of days with snow cover throughout the winter period in particular seasons was determined. Next, changes in snow cover depth were analysed for the study period. The frequency of occurrence of days with a decrease and increase in snow cover depth was calculated for pentads in winter seasons. At the final stage of data processing, dates of the first and last day of particular seasons of snow cover occurrence were designated, permitting the determination of the duration (in days) of particular seasons. The level of significance of trends was also determined. The statistical assessment of changes applied a nonparametric Mann-Kendall test, and their statistical significance was assessed by means of the Sen method (Salmi et al. 2002). Due to the date of appearance of first snow and its disappearance, winter season was defined as

Table 1 Classification of snow cover depth by Chrzanowski (1988)

\begin{tabular}{ll}
\hline Type of snow cover & $\begin{array}{l}\text { Depth of } \\
\text { snow cover } \\
{[\mathrm{cm}]}\end{array}$ \\
\hline No cover & 0 \\
Trace & $\leq 1$ \\
Thin & $2-5$ \\
Moderate & $6-10$ \\
Thick & $11-20$ \\
Very thick & $21-30$ \\
Exceptionally thick & $>30$ \\
\hline
\end{tabular}

the period from October to May. For winter season, circulation types based on the Grosswetterlagen classification (Table 2; James 2007) were defined, and the frequency was calculated. Next, for days with snow cover, the probability of occurrence of such days in particular circulation types was determined.

The "Grosswetterlagen" focusses on similar atmospheric processes in a larger area, e.g. Europe. The first calendar of European Grosswetterlagen comprised 21 GWL. Baur's initial concept was further developed and extended to $29 \mathrm{GWL}$ in the following decades by Hess and Brezowsky (1977), therefore also known under their name. Later updates were published by Gerstengarbe and Werner (2005). Its development involved the use of surface synoptic maps and geopotential height charts at the $500 \mathrm{hPa}$ level, with consideration of direction of air flow and location of pressure systems. A total of 30 circulation types were distinguished, additionally grouped in Grosswettertypen (GWT) by air mass advection (Gerstengarbe and Werner 2005). The objective method for classifying synoptic weather regimes over Europe and the North East Atlantic, based closely on the widely used Grosswetterlagen (GWL) series of Hess and Brezowsky, was constructed by James (2007), in which a pattern correlation technique is used to find the best matching types from a set of pre-defined patterns representing the respective GWLs.

Since such circulation biases are hard to assimilate easily when 29 types are used, the GWLs were concatenated into a small set of basic circulation types representing westerly, northerly, easterly, southerly, central, and cyclonic or anticyclonic circulation types, respectively (Table 3). Mixed types are grouped into both adjacent circulation types with halfweighting, respectively (e.g. northerly and westerly in the case of NWZ). In all cases, the circulation type definition is based on the character of circulation over Central Europe (James 2007). Developed for Central Europe (Germany), the GWL concept works well for a much larger region, covering all of Europe (Khokhlov and Umanska 2018). The typology has been used in numerous papers investigating Central Europe (Bardossy and Caspary, 1990; Keevallik et al. 1999; Kaszewski and Filipiuk 2003; Kyselý and Domonkos 2006; Ustrnul 2006; Ustrnul et al. 2014; Tomczyk et al. 2015; Bartoszek and Skiba 2016).

\section{Results}

\subsection{Number of days with snow cover}

Particular winter seasons in Poznań were relatively strongly variable in terms of number of days with snow cover. The winter 1969/1970 stands out the most with the occurrence of 121 days with snow cover, whereas there was no snow cover in Poznań in winter 2019/2020. The least snowy winter 
Table 2 Definitions of the circulation types (GWT) and the atmospheric circulation patterns (GWL) (James 2007)

\begin{tabular}{|c|c|c|}
\hline $\begin{array}{l}\text { Circulation Type (Grosswet- } \\
\text { tertype; GWT) }\end{array}$ & Symbol & Atmospheric circulation patterns (Grosswetterlage; GWL) \\
\hline \multirow[t]{6}{*}{ North } & HB & British Isles High \\
\hline & HNA & Norwegian Sea High, anticyclonic \\
\hline & $\mathrm{HNZ}$ & Norwegian Sea High. cyclonic \\
\hline & NA & North Circulation, anticyclonic \\
\hline & $\mathrm{NZ}$ & North Circulation, cyclonic \\
\hline & TRM & Central Europe Trough \\
\hline \multirow[t]{2}{*}{ Northeast } & NEA & Northeast Circulation, anticyclonic \\
\hline & NEZ & Northeast Circulation, cyclonic \\
\hline \multirow[t]{4}{*}{ East } & HFA & Fennoscandian High, anticyclonic \\
\hline & HFZ & Fennoscandian High, cyclonic \\
\hline & HNFA & Norwegian Sea/Fennoscandia High, anticyclonic \\
\hline & HNFZ & Norwegian Sea/Fennoscandia High, cyclonic \\
\hline \multirow[t]{2}{*}{ Southeast } & SEA & Southeast Circulation, anticyclonic \\
\hline & SEZ & Southeast Circulation, cyclonic \\
\hline \multirow[t]{4}{*}{ South } & SA & South Circulation, anticyclonic \\
\hline & SZ & South Circulation, cyclonic \\
\hline & $\mathrm{TB}$ & British Isles Low \\
\hline & TRW & Western Europe Trough \\
\hline \multirow[t]{2}{*}{ Southwest } & SWA & Southwest Circulation, anticyclonic \\
\hline & SWZ & Southwest Circulation, cyclonic \\
\hline \multirow[t]{4}{*}{ West } & WA & West Circulation, anticyclonic \\
\hline & WS & West Circulation, cyclonic \\
\hline & WZ & Southern West Circulation \\
\hline & WW & Angled West Circulation \\
\hline \multirow[t]{2}{*}{ Northwest } & NWA & Northwest Circulation, anticyclonic \\
\hline & NWZ & Northwest Circulation, cyclonic \\
\hline \multirow[t]{2}{*}{ Central Europe High } & HM & Central European High \\
\hline & BM & Central European Ridge \\
\hline \multirow[t]{2}{*}{ Central Europe Low } & TM & Central European Low \\
\hline & $\mathrm{U}$ & Undefined \\
\hline
\end{tabular}

Table 3 Definition of the circulation types and their associated atmospheric circulation patterns

\begin{tabular}{|c|c|c|}
\hline \multirow[t]{2}{*}{ Circulation type } & \multicolumn{2}{|l|}{ Associated Grosswetterlagen } \\
\hline & Full weight & Half weight \\
\hline Westerly & WA, WZ, WS, WW & SWA, SWZ, NWA, NWZ \\
\hline Northerly & NA, NZ, HNA, HNZ, HB, TRM & NWA, NWZ, NEA, NEZ \\
\hline Easterly & HFA, HFZ, HNFA, HNFZ & SEA, SEZ, NEA, NEZ \\
\hline Southerly & SA, SZ, TB, TRW & SWA, SWZ, SEA, SEZ \\
\hline Central & HM, BM, TM & \\
\hline Cyclonic & $\begin{array}{l}\text { WZ, WS, WW, SWZ, NWZ, TM, NZ, HNZ, TRM, NEZ, HFZ, HNFZ, SEZ, SZ, TB, } \\
\text { TRW }\end{array}$ & \\
\hline Anticyclonic & WA, SWA, NWA, HM, BM, NA, HNA, HB, NEA, HFA, HNFA, SEA, SA & \\
\hline
\end{tabular}

was observed also in winter 1988/1989, when snow cover occurred only once in the entire season.

The number of days with snow cover is largely variable from year to year. A decreasing, statistically significant trend of 5.3 days/10 years $(p<0.05)$ is observed in the analysed multiannual period 1966/1967-2019/2020 (Fig. 1). A small number of days with snow cover have been recorded in subsequent years since the season 2013/2014. 
Fig. 1 Number of days with snow cover in Poznań in winter seasons 1966/1967-2019/2020

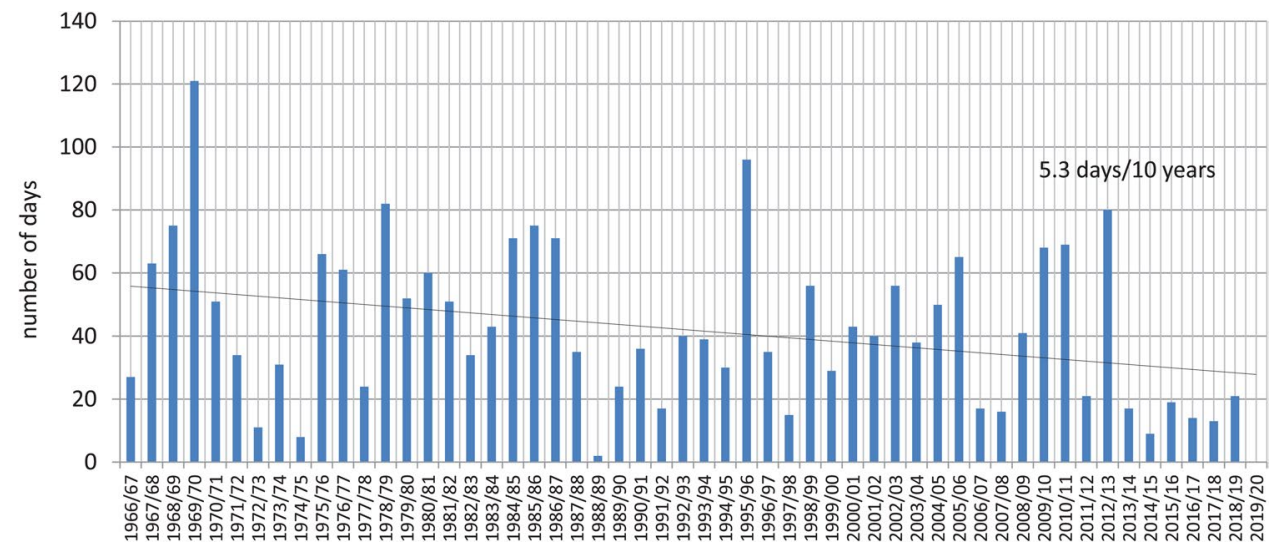

A decreasing, statistically significant trend at the level of $p<0.1$ is observed for the duration of the winter seasons in the analysed multiannual period 1966/1967-2019/2020 (Table 4). A higher number of days with snow cover do not mean an increase in the duration of particular seasons, and longer seasons do not mean a proportionate increase in the number of days with snow cover. For example, winter 1989/1990 had only 24 days with snow cover, and the entire season lasted exactly 100 days. There are years in which a longer season meant more days with snow cover, for example, winter 1969/1970, when a total of 131 days in the season included 121 days with snow cover. No snow cover was recorded only on 10 days then. The longest snowy season lasted 166 days in 1995/1996, but there were 71 days with snow cover then. The dates of the beginning and end of particular seasons with their duration are presented in the table below (Table 4).

\subsection{Snow cover depth and its variability}

Snow cover thickness in Poznań changed considerably with years. Mean snow cover thickness calculated for days with snow cover in the analysed multiannual period varied from $0 \mathrm{~cm}$ in season $2019 / 2020$ and $1 \mathrm{~cm}$ in season $1988 / 1989$ to as much as $19 \mathrm{~cm}$ in season $1969 / 1970$. Considering the maximum thickness of snow cover, its record value was observed in season 1969/1970, reaching $46 \mathrm{~cm}$ (Table 5).

The snowiness of winters in the multiannual period 1966/1967-2019/2020 is indicated by the winter snowiness coefficient proposed by Paczos (1982), calculated for the period from December to March. Most winters in Poznań was characterized by low snowiness: extremely low (33.3\%), unusually low $(31.5 \%)$, and very low $(24.0 \%)$. The snowiness index varied from 0 to 6.4 , and its mean value was 1.7 . In accordance with the coefficient, the snowiest winter was that at the turn of 1969/70, when the coefficient reached the highest value of 6.4. Winter $1978 / 1979$ with a value of 4.3 is also worth attention. In the remaining years, the snowiness coefficient did not exceed 4. Among less snowy winters, seasons 1995/1996, 2009/2010, 2010/2011, and 2012/2013 also stand out. Except the snowless winter 2019/2020, the lowest value of the snowiness coefficient was recorded for winter 1988/1989. It was 0.04 (Fig. 2a). A decreasing, statistically significant trend at the level of $p<0.05$ was observed for the winter snowiness in the analysed multiannual period 1966/1967-2019/2020. The shorter snow cover, which covers smaller areas, contributes to an additional increase in air temperature.

The severity of winters in the research period is indicated by the winter severity index (Paczos 1985). The majority of winter seasons in Poznań are classified as mild (40.7\%) and very mild (22.2\%). The winter severity index varied from 0 to 5.3 , and its mean value was 2.1 (Fig. 2b). The coldest winter was that of $1969 / 1970$ season (5.3) classified as a moderately severe. The mildest one was the $2019 / 2020$ season (0.01). During most winters the severity index did not exceed the value of 2 . A decreasing, statistically significant trend at the level of $p>0.1$ indicates in the study period.

Both discussed indicators follow a similar course over many years. It suggests the dependence between them. A statistically significant positive correlation was found $(r=0.89)$ between the thermal severity and snowiness index in winters in Poznan; that is, the increase in the severity of winter is usually accompanied by an increase in its snowiness. It is reflected in the distinguished types of winters. The affiliation of winters to thermal-snow types is presented in Table 6. The most $-46.3 \%$ were moderately severe and moderately snowy winters. Then the mild and moderately snowy winters occurred with the $22.2 \%$ frequency. This character seems to be typical of the Polish climate. The group of severe and snowy winters includes 8 , including 3 after 2000 (2009/2010, 2010/2011, 2012/2013). The severe and moderately snowy were 3 winters. The moderately severe and low snowy were 2 seasons. And the mild and low snowy winters occurred 4 times. Among the obtained types, there were no two extreme types of winters: mild and snowy, and severe and low snow, but also the moderately severe and snowy winters. This is due to physical conditions. In the 
Table 4 Dates of the beginning, end, and duration of winter seasons 1966/1967-2019/2020 in Poznań

\begin{tabular}{|c|c|c|c|}
\hline Season & First day & Last day & Duration (days) \\
\hline $1966 / 67$ & 01.12 & 25.01 & 56 \\
\hline $1967 / 68$ & 28.11 & 15.03 & 109 \\
\hline $1968 / 69$ & 16.11 & 28.03 & 133 \\
\hline $1969 / 70$ & 27.11 & 06.04 & 131 \\
\hline $1970 / 71$ & 22.12 & 13.03 & 82 \\
\hline $1971 / 72$ & 22.11 & 09.02 & 80 \\
\hline $1972 / 73$ & 21.01 & 26.02 & 37 \\
\hline $1973 / 74$ & 27.11 & 25.02 & 91 \\
\hline $1974 / 75$ & 14.12 & 29.03 & 106 \\
\hline $1975 / 76$ & 22.11 & 23.03 & 123 \\
\hline $1976 / 77$ & 24.11 & 12.04 & 140 \\
\hline $1977 / 78$ & 29.11 & 23.03 & 115 \\
\hline $1978 / 79$ & 17.12 & 22.03 & 96 \\
\hline $1979 / 80$ & 02.11 & 14.03 & 134 \\
\hline $1980 / 81$ & 30.11 & 02.03 & 93 \\
\hline $1981 / 82$ & 06.12 & 29.01 & 55 \\
\hline $1982 / 83$ & 19.12 & 02.03 & 74 \\
\hline $1983 / 84$ & 16.11 & 25.02 & 102 \\
\hline $1984 / 85$ & 18.11 & 02.05 & 166 \\
\hline $1985 / 86$ & 20.11 & 13.04 & 145 \\
\hline $1986 / 87$ & 22.12 & 21.03 & 90 \\
\hline $1987 / 88$ & 08.12 & 16.03 & 100 \\
\hline $1988 / 89$ & 08.01 & 08.01 & 1 \\
\hline $1989 / 90$ & 22.11 & 01.03 & 100 \\
\hline 1990/91 & 01.12 & 23.02 & 85 \\
\hline $1991 / 92$ & 26.12 & 27.03 & 93 \\
\hline $1992 / 93$ & 12.12 & 31.03 & 110 \\
\hline $1993 / 94$ & 20.11 & 20.03 & 121 \\
\hline $1994 / 95$ & 22.12 & 30.03 & 99 \\
\hline $1995 / 96$ & 03.11 & 14.04 & 164 \\
\hline $1996 / 97$ & 27.11 & 06.04 & 131 \\
\hline $1997 / 98$ & 25.10 & 22.03 & 149 \\
\hline $1998 / 99$ & 15.11 & 24.02 & 102 \\
\hline $1999 / 00$ & 21.11 & 17.03 & 118 \\
\hline $2000 / 01$ & 25.12 & 28.03 & 94 \\
\hline $2001 / 02$ & 15.12 & 16.03 & 92 \\
\hline $2002 / 03$ & 17.12 & 10.04 & 115 \\
\hline $2003 / 04$ & 12.12 & 08.03 & 88 \\
\hline $2004 / 05$ & 20.11 & 16.03 & 117 \\
\hline $2005 / 06$ & 19.11 & 15.03 & 117 \\
\hline $2006 / 07$ & 29.12 & 28.02 & 62 \\
\hline $2007 / 08$ & 26.11 & 27.03 & 123 \\
\hline $2008 / 09$ & 25.11 & 26.03 & 122 \\
\hline $2009 / 10$ & 14.12 & 16.03 & 93 \\
\hline $2010 / 11$ & 27.11 & 04.03 & 98 \\
\hline $2011 / 12$ & 22.12 & 18.02 & 59 \\
\hline $2012 / 13$ & 04.12 & 07.04 & 125 \\
\hline $2013 / 14$ & 06.12 & 01.02 & 58 \\
\hline $2014 / 15$ & 31.12 & 09.02 & 41 \\
\hline
\end{tabular}

Table 4 (continued)

\begin{tabular}{lccl}
\hline Season & First day & Last day & Duration (days) \\
\hline $2015 / 16$ & 02.01 & 09.03 & 68 \\
$2016 / 17$ & 08.01 & 25.01 & 18 \\
$2017 / 18$ & 14.12 & 07.03 & 84 \\
$2018 / 19$ & 15.12 & 06.02 & 54 \\
$2019 / 20$ & - & - & 0 \\
\hline
\end{tabular}

case of mild and snowy winters, it is practically impossible for a significant snow cover to remain in the absence of a preservative, i.e. negative temperature for a long time. On the other hand, the lack of severe and low snowy winters can be explained by the nature of the general atmospheric circulation in moderate latitudes.

The sum of snow cover depth in particular seasons showed high variability (Fig. 3). Throughout the study period, the highest values occurred in season 1969/1970. A total of $2341 \mathrm{~cm}$ of snow fell throughout the season. The second snowiest winter occurred at the turn of 1978 and 1979 , with snowfall of $1342 \mathrm{~cm}$. The value of more than $1000 \mathrm{~cm}$ was also exceeded in winter 2009/2010. A total of $1071 \mathrm{~cm}$ of snow fell in that season. During the next season, the snow cover thickness was still above average, although in comparison to the previous season, $197 \mathrm{~cm}$ less snow was observed. There was no snow cover in winter 2019/2020. The least snow fell during winter 1988/1989-only $1 \mathrm{~cm}$. The average from the entire period 1966-2020 is $302 \mathrm{~cm}$. In spite of several snowy winters, the trend for the entire multiannual period is evidently decreasing (statistically significant at the level of 0.05). The total snow cover thickness in particular seasons was variable, but the majority of winters did not exceed a value of $500 \mathrm{~cm}$. Since season 2013/2014, total snow cover depth in particular seasons varied from 47 to $0 \mathrm{~cm}$. Significant global temperature changes are associated with declining snow cover, and extremely warm winters occurring most frequently in recent years proved to be also least snowy.

The classification by Chrzanowski permits the determination of the share of particular types of snow cover (Table 1). In the majority of years, the highest percent share concerns days without snow cover (Fig. 4). In the case of the remaining values, the share is largely variable. In snowy seasons, for example, 1969/1970 or 1978/1979, thick snow cover $(11-20 \mathrm{~cm})$ had the highest share, and in seasons with a small amount of snow, thin snow cover $(2-5 \mathrm{~cm})$ was prevalent. In winter $1988 / 1989$, the entire season lasted one day, with a $1 \mathrm{~cm}$ snow cover. An exceptionally high share of thin cover is observed in the season 2016/2017, reaching 55\%. In winter 1969/1970, a large share of exceptionally thick snow cover $(>30 \mathrm{~cm})$ was observed, exceeding 9\%. Also, the season 2009/2010 
Table 5 Snow cover depth in winter seasons 1966/19672019/2020 in Poznań

\begin{tabular}{|c|c|c|c|c|}
\hline \multirow[t]{3}{*}{ Winter season } & \multicolumn{3}{|c|}{ Snow cover depth $[\mathrm{cm}]$} & \multirow{3}{*}{$\begin{array}{l}\text { Number of days } \\
\text { with snow cover }\end{array}$} \\
\hline & \multicolumn{2}{|l|}{ Mean for } & \multirow[t]{2}{*}{ Maximum } & \\
\hline & $\begin{array}{l}\text { Days with snow } \\
\text { cover }\end{array}$ & All days & & \\
\hline $1966 / 67$ & 2.8 & 0.3 & 7 & 27 \\
\hline $1967 / 68$ & 6.1 & 1.6 & 22 & 63 \\
\hline $1968 / 69$ & 9.1 & 2.8 & 24 & 75 \\
\hline $1969 / 70$ & 19.3 & 9.6 & 46 & 121 \\
\hline 1970/71 & 9.3 & 2.0 & 16 & 51 \\
\hline $1971 / 72$ & 4.4 & 0.6 & 14 & 34 \\
\hline $1972 / 73$ & 1.8 & 0.1 & 4 & 8 \\
\hline $1973 / 74$ & 4.4 & 0.6 & 13 & 31 \\
\hline $1974 / 75$ & 1.4 & 0.0 & 2 & 8 \\
\hline $1975 / 76$ & 3.9 & 1.1 & 14 & 66 \\
\hline 1976/77 & 6.5 & 1.6 & 12 & 61 \\
\hline $1977 / 78$ & 2.9 & 0.3 & 7 & 24 \\
\hline $1978 / 79$ & 16.4 & 5.5 & 29 & 82 \\
\hline $1979 / 80$ & 5.0 & 1.1 & 14 & 52 \\
\hline 1980/81 & 6.3 & 1.6 & 13 & 60 \\
\hline $1981 / 82$ & 8.8 & 1.8 & 19 & 49 \\
\hline $1982 / 83$ & 13.8 & 1.9 & 25 & 34 \\
\hline $1983 / 84$ & 2.8 & 0.5 & 6 & 43 \\
\hline $1984 / 85$ & 6.7 & 1.9 & 14 & 68 \\
\hline $1985 / 86$ & 9.3 & 2.9 & 19 & 75 \\
\hline 1986/87 & 6.7 & 2.0 & 20 & 71 \\
\hline $1987 / 88$ & 4.8 & 0.7 & 13 & 34 \\
\hline $1988 / 89$ & 1.0 & 0.0 & 1 & 1 \\
\hline $1989 / 90$ & 3.9 & 0.4 & 14 & 24 \\
\hline 1990/91 & 5.9 & 0.9 & 13 & 36 \\
\hline $1991 / 92$ & 2.0 & 0.1 & 10 & 17 \\
\hline $1992 / 93$ & 4.4 & 0.7 & 11 & 39 \\
\hline $1993 / 94$ & 6.1 & 1.0 & 14 & 39 \\
\hline $1994 / 95$ & 3.6 & 0.4 & 8 & 30 \\
\hline $1995 / 96$ & 3.0 & 1.2 & 11 & 96 \\
\hline 1996/97 & 1.6 & 0.2 & 5 & 35 \\
\hline $1997 / 98$ & 2.3 & 0.1 & 7 & 11 \\
\hline $1998 / 99$ & 5.6 & 1.3 & 14 & 56 \\
\hline $1999 / 00$ & 3.8 & 0.5 & 12 & 29 \\
\hline $2000 / 01$ & 3.0 & 0.5 & 8 & 42 \\
\hline $2001 / 02$ & 6.4 & 1.0 & 22 & 40 \\
\hline $2002 / 03$ & 5.2 & 1.2 & 11 & 56 \\
\hline $2003 / 04$ & 5.5 & 0.9 & 16 & 38 \\
\hline $2004 / 05$ & 9.7 & 2.0 & 22 & 50 \\
\hline $2005 / 06$ & 4.9 & 1.3 & 13 & 65 \\
\hline 2006/07 & 4.8 & 0.3 & 12 & 17 \\
\hline 2007/08 & 1.8 & 0.1 & 7 & 16 \\
\hline $2008 / 09$ & 3.0 & 0.5 & 12 & 41 \\
\hline $2009 / 10$ & 15.8 & 4.4 & 33 & 68 \\
\hline 2010/11 & 12.7 & 3.6 & 28 & 69 \\
\hline 2011/12 & 4.9 & 0.4 & 20 & 21 \\
\hline $2012 / 13$ & 8.7 & 2.9 & 19 & 80 \\
\hline
\end{tabular}


Table 5 (continued)

Fig. 2 Winter snowiness coefficient (a) and winter severity index (b) in Poznań in seasons 1966/1967-2019/2020

\begin{tabular}{|c|c|c|c|c|}
\hline \multirow[t]{3}{*}{ Winter season } & \multicolumn{3}{|c|}{ Snow cover depth $[\mathrm{cm}]$} & \multirow{3}{*}{$\begin{array}{l}\text { Number of days } \\
\text { with snow cover }\end{array}$} \\
\hline & \multicolumn{2}{|l|}{ Mean for } & \multirow[t]{2}{*}{ Maximum } & \\
\hline & $\begin{array}{l}\text { Days with snow } \\
\text { cover }\end{array}$ & All days & & \\
\hline $2013 / 14$ & 2.4 & 0.2 & 6 & 17 \\
\hline $2014 / 15$ & 2.2 & 0.1 & 4 & 9 \\
\hline $2015 / 16$ & 2.5 & 0.2 & 10 & 19 \\
\hline $2016 / 17$ & 2.7 & 0.2 & 5 & 14 \\
\hline $2017 / 18$ & 2.4 & 0.1 & 4 & 13 \\
\hline $2018 / 19$ & 1.5 & 0.1 & 3 & 21 \\
\hline $2019 / 20$ & 0.0 & 0.0 & 0 & 0 \\
\hline Average & 5.4 & 1.4 & 13 & 41 \\
\hline Standard deviation & 4.0 & 1.6 & 8 & 25 \\
\hline Coefficient of variation [\%] & 0.7 & 1.2 & 0.6 & 0.6 \\
\hline
\end{tabular}

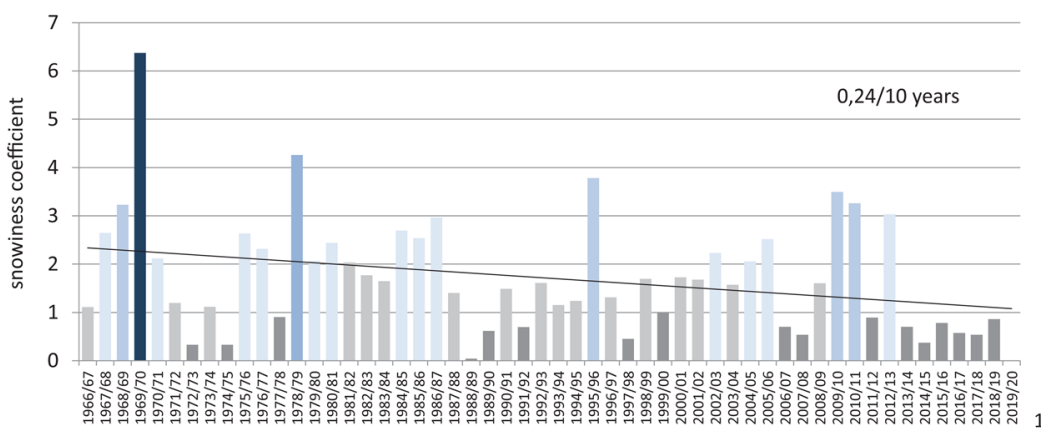

(a)
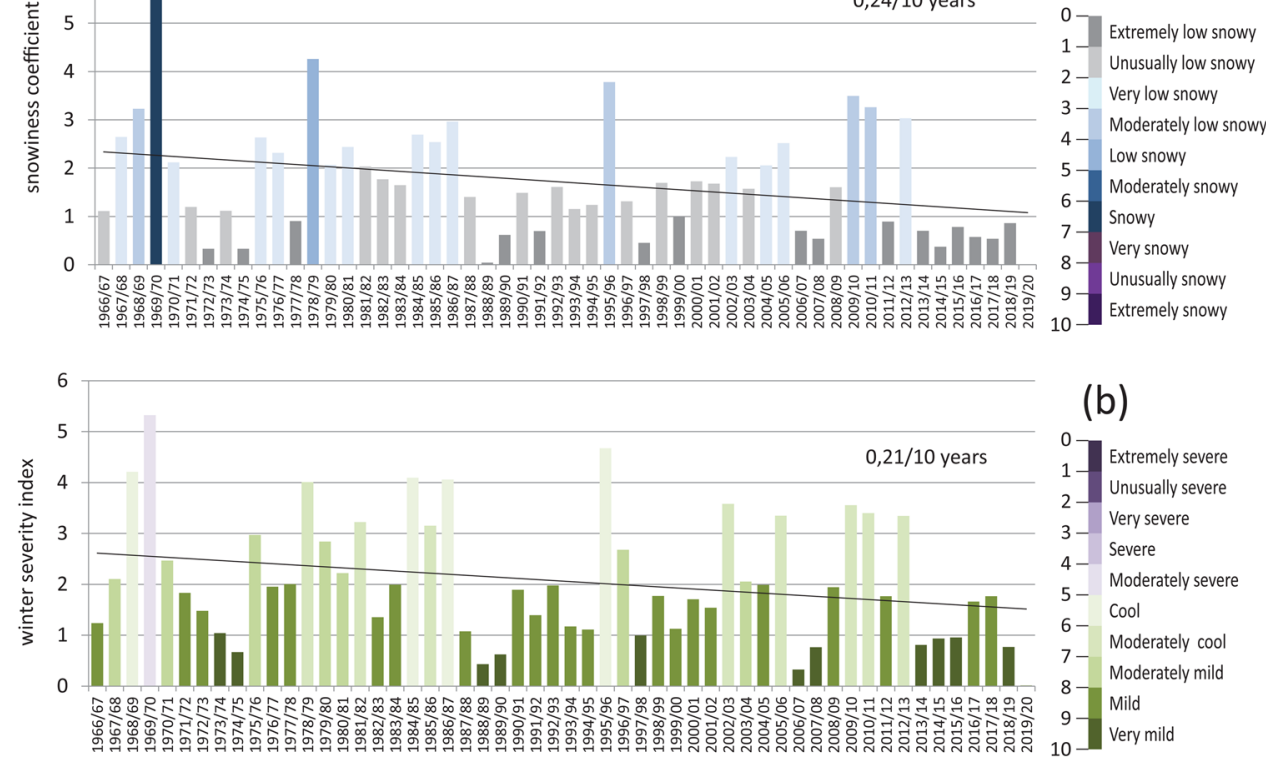

(b)

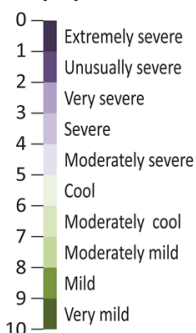

Table 6 Snowiness and thermal classification of winter seasons in Poznań (1966/1967-2019/2020)

\begin{tabular}{llll}
\hline Type & Severe & Moderately severe & Mild \\
\hline Snowy & $1968 / 69,1969 / 70,1978 / 79,1986 / 87$, & & - \\
& $1995 / 96,2009 / 10,2010 / 11,2012 / 13$ & & \\
Moderately snowy & $1984 / 85,2002 / 03,2005 / 06$ & $1966 / 67,1967 / 68,1970 / 71,1971 / 72$, & $1989 / 90,1990 / 91,1991 / 92,1992 / 93$, \\
& & $1973 / 74,1975 / 76,1976 / 77,1977 / 78$, & $1993 / 94,1994 / 95,1996 / 97$, \\
& & $1979 / 80,1980 / 81,1981 / 82,1982 / 83$, & $2006 / 07,2007 / 08,2011 / 12$, \\
& $1983 / 84,1985 / 86,1987 / 88,1998 / 99$, & $2013 / 14,2018 / 19$ \\
& & $1999 / 00,2000 / 01,2001 / 02,2003 / 04$, & \\
Low snowy & - & $2004 / 05,2008 / 09,2015 / 16,2016 / 17$, & \\
& & $2017 / 18$ & $1974 / 75,1988 / 89,2014 / 15,2019 / 20$ \\
\hline
\end{tabular}


Fig. 3 Total snow cover depth $(\mathrm{cm})$ in Poznań in the years 1966/1967-2019/2020

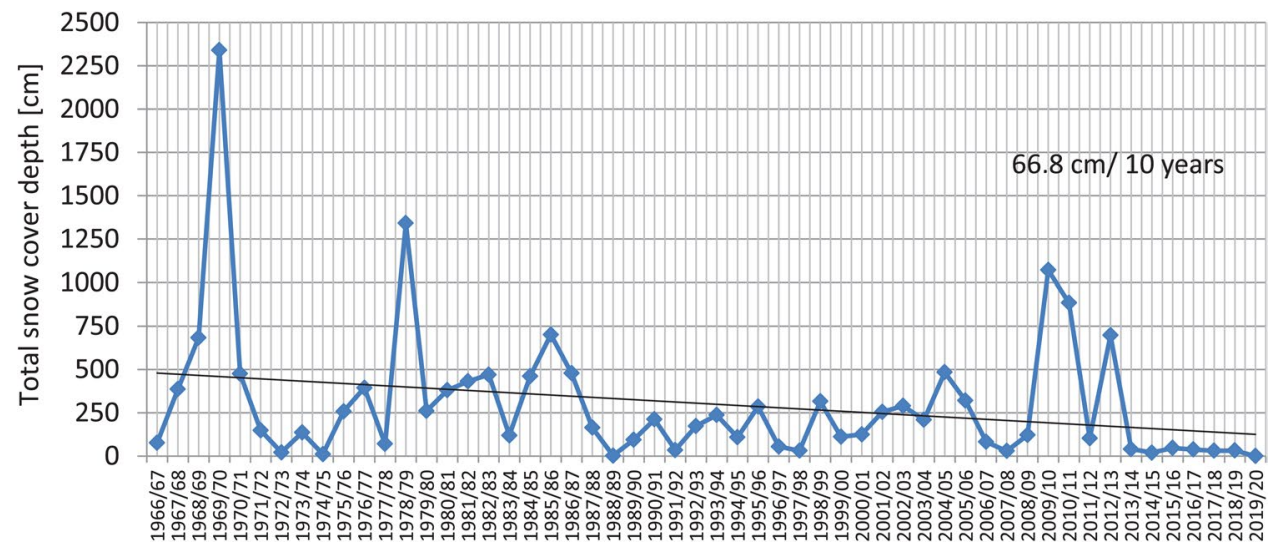

Fig. 4 The share (\%) of days with variable snow cover depth in Poznań in winter seasons 1966/1967-2019/2020

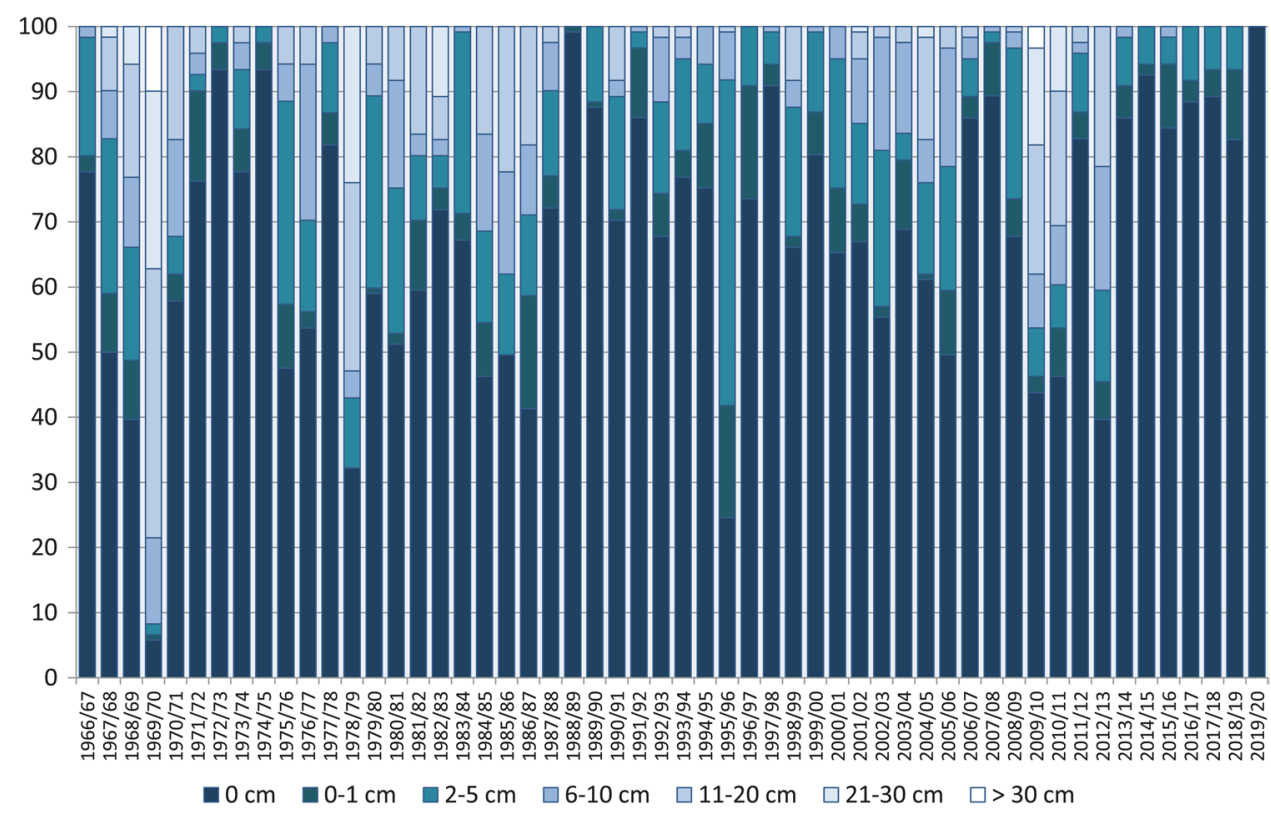

showed a share of exceptionally thick snow cover, although in this case it reached 4\%. Almost every season showed a considerable share of thin cover and a substantially lower share of trace cover $(\leq 1 \mathrm{~cm})$. An increase in temperature in winter months is considerably affecting the formation and permanence of snow cover; hence, more and more often the snow cover rarely exceeds $5 \mathrm{~cm}$.

Considering the mean depth of snow cover from the multiannual period for each month, the month most abundant in snow was January, with a mean thickness at a level of $3.5 \mathrm{~cm}$. February comes second with a mean thickness of approximately $3.3 \mathrm{~cm}$. The value of $1 \mathrm{~cm}$ is also exceeded in 2 more months, namely December and March, and in the remaining months, the value of $0.5 \mathrm{~cm}$ was not exceeded (Fig. 5).

Considering multiannual daily means, the highest abundance of snow in the analysed seasons was recorded in the first half of January and second half of February (Fig. 6). The frequency of days with snow cover varied

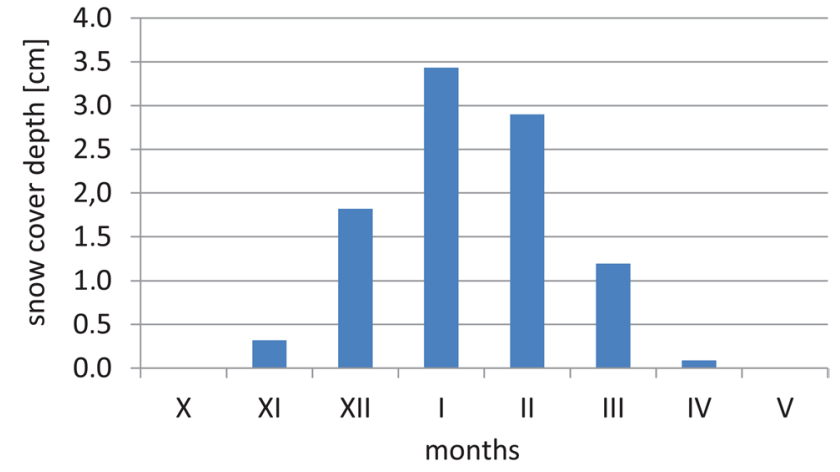

Fig. 5 Average snow cover depth $(\mathrm{cm})$ in particular months of the winter season in Poznań in the years 1966/1967-2019/2020

in the winter period from occasional cases of snow cover occurrence at the beginning and end of the winter season to around $55 \%$ in January and after a mid-winter decline up to $46 \%$ in February. Mean snow cover depth increased 
Fig. 6 Frequency of occurrence (\%) of days with an increase (the dashed line) and decrease (the dotted line) in snow cover depth in Poznań-7-pentad running averages for the years 1966/1967-2019/2020

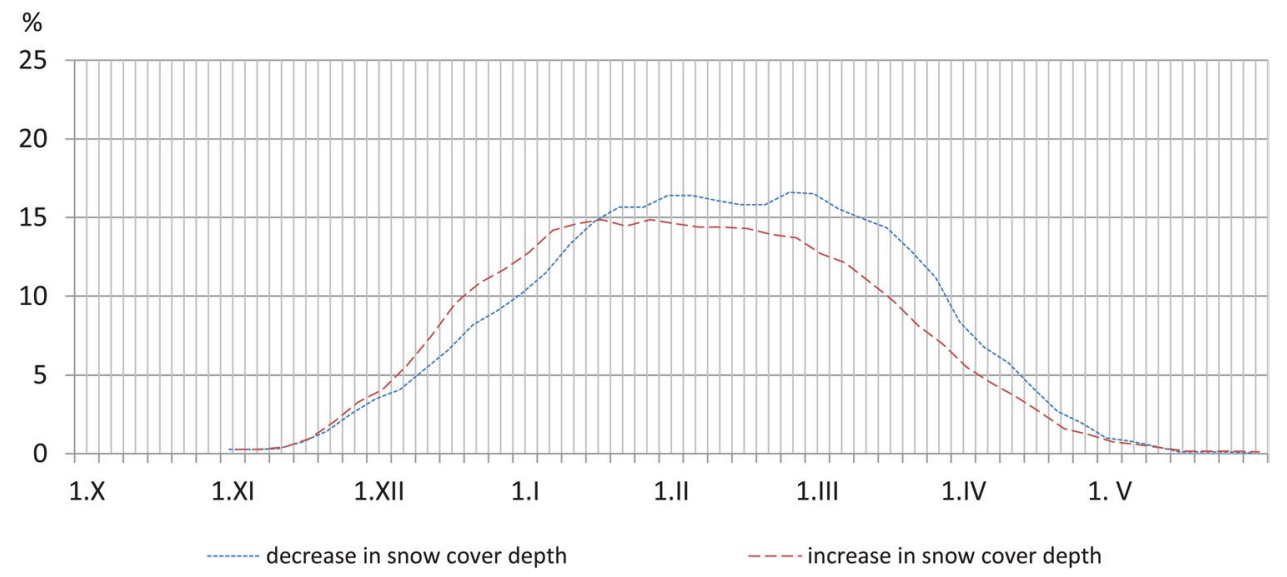

with day-to-day fluctuations until mid-January, when the highest value of $4.0 \mathrm{~cm}$ was observed. It was followed by a decrease, and the second increase was recorded at the end of January, when mean snow cover thickness reached a value of $3.7 \mathrm{~cm}$. After another large decrease, mean snow cover depth increased again. In the second half of February, it reached a value of $4.4 \mathrm{~cm}$. Maximum of the number of days with snow cover were recorded in the first half of January and the snow cover depth in February (Fig. 6). At the turn of January and February, mean snow cover depth decreased with a simultaneous decrease in the frequency of days with snow cover. The difference in the course of mean snow cover depth and frequency of days with snow cover suggests higher snow cover thickness in the second half of the winter season.

The maximum frequency of days with an increase occurred in January. The frequency of days with a decrease was the highest from the mid-January, and the maximum occurred at the beginning of March. From December to mid-January, days with an increase occurred more frequently, and from mid-January to the beginning of May, days with a decrease in snow cover thickness were more frequent. The greatest discrepancy was observed in March, when days with a decrease occurred more frequently (Fig. 7).

\subsection{Snow cover and the atmosphere circulation impact}

Winter weather conditions are strongly influenced by the atmosphere circulation, which is responsible for a great in-seasonal and multiannual variability of thermal conditions and snowiness.

In the years 1966-2020, the frequency of circulation types based on the Grosswetterlagen classification were calculated in the whole period of winter seasons. Then, for the days with snow cover only, the probability of occurrence of such days in particular circulation types were determined.

The circulation type WZ (15.3\%) and BM (9.6\%) occurred in the winter season the most frequently in the analysed period (Fig. 8). The least frequent types, with frequency below $1 \%$, included types NA (0.6\%), NEA (0.8\%), and SZ $(0.9 \%)$. In the study period in winter, cyclonic circulation was predominant (58.6\%) over anticyclonic circulation (40.3\%).

The highest probability of occurrence of days with snow cover was recorded during type WS (38.8\%) (Fig. 9a). High probability was also determined for types: NZ (38.6\%) and HNFZ (35.4\%). The lowest chance of occurrence of a day with snow cover was recorded for types TRW (5.6\%), NWA and SWA (6.5\% each), and SA (7.0\%). A higher probability of occurrence of snow cover was also observed
Fig. 7 The change in the average snow cover depth $(\mathrm{cm})$ and frequency of days with snow cover (\%) in Poznań in seasons 1966/1967-2019/2020

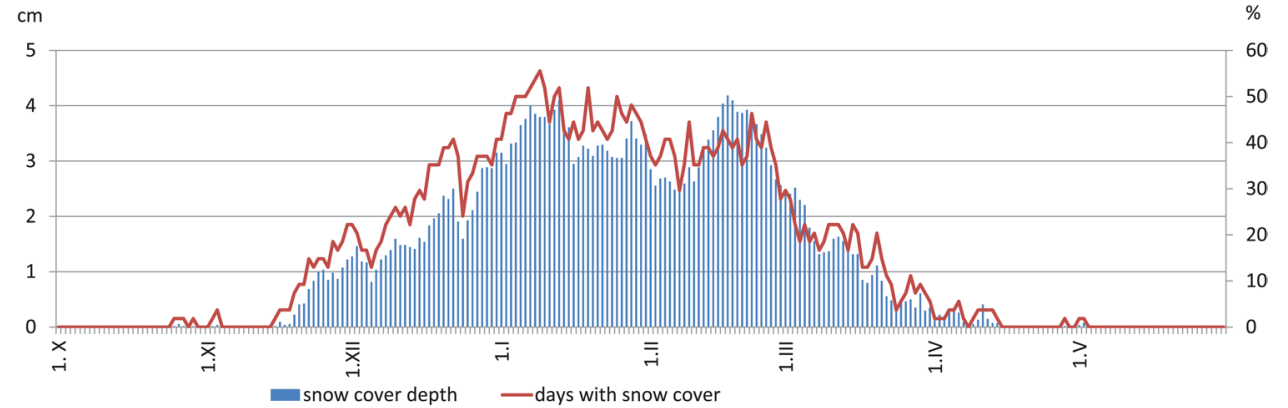



ticular GWL circulation types in winter seasons 1966/19672019/2020. Explanations of the GWL types: see Table 2
Fig. 8 The occurrence of par-

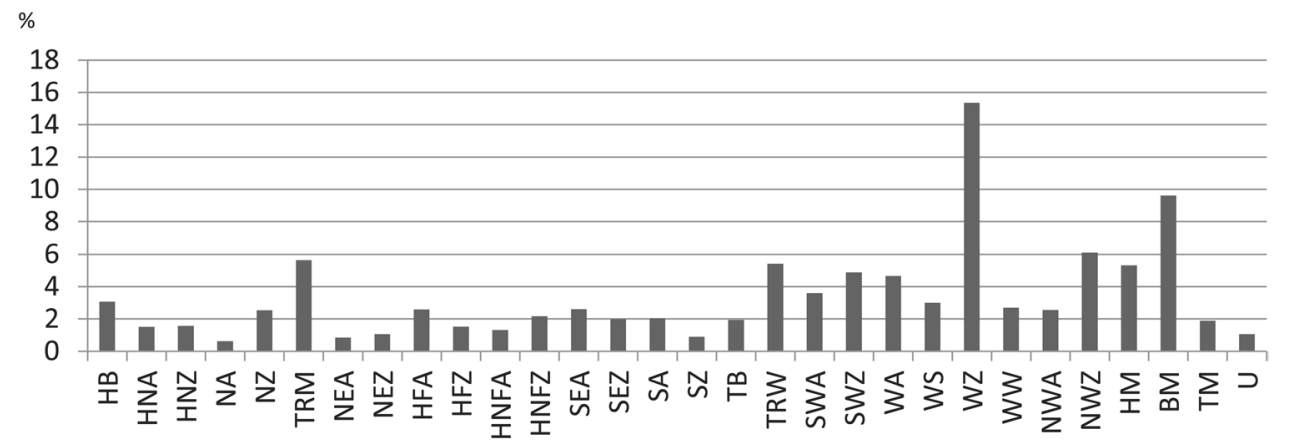

Fig. 9 Probability of the occurrence of days' number with a snow cover, $\mathbf{b}$ snow cover increase, and $\mathbf{c}$ snow cover decrease in the particular GWL circulation types in the winter seasons 1966/1967-2019/2020. Explanations of the GWL types: see Table 2

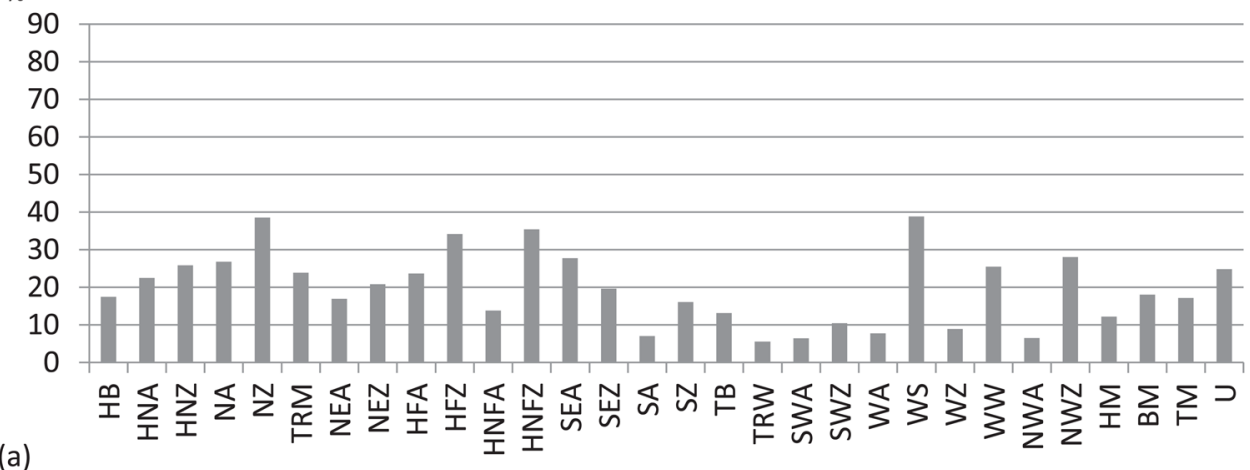

(a)
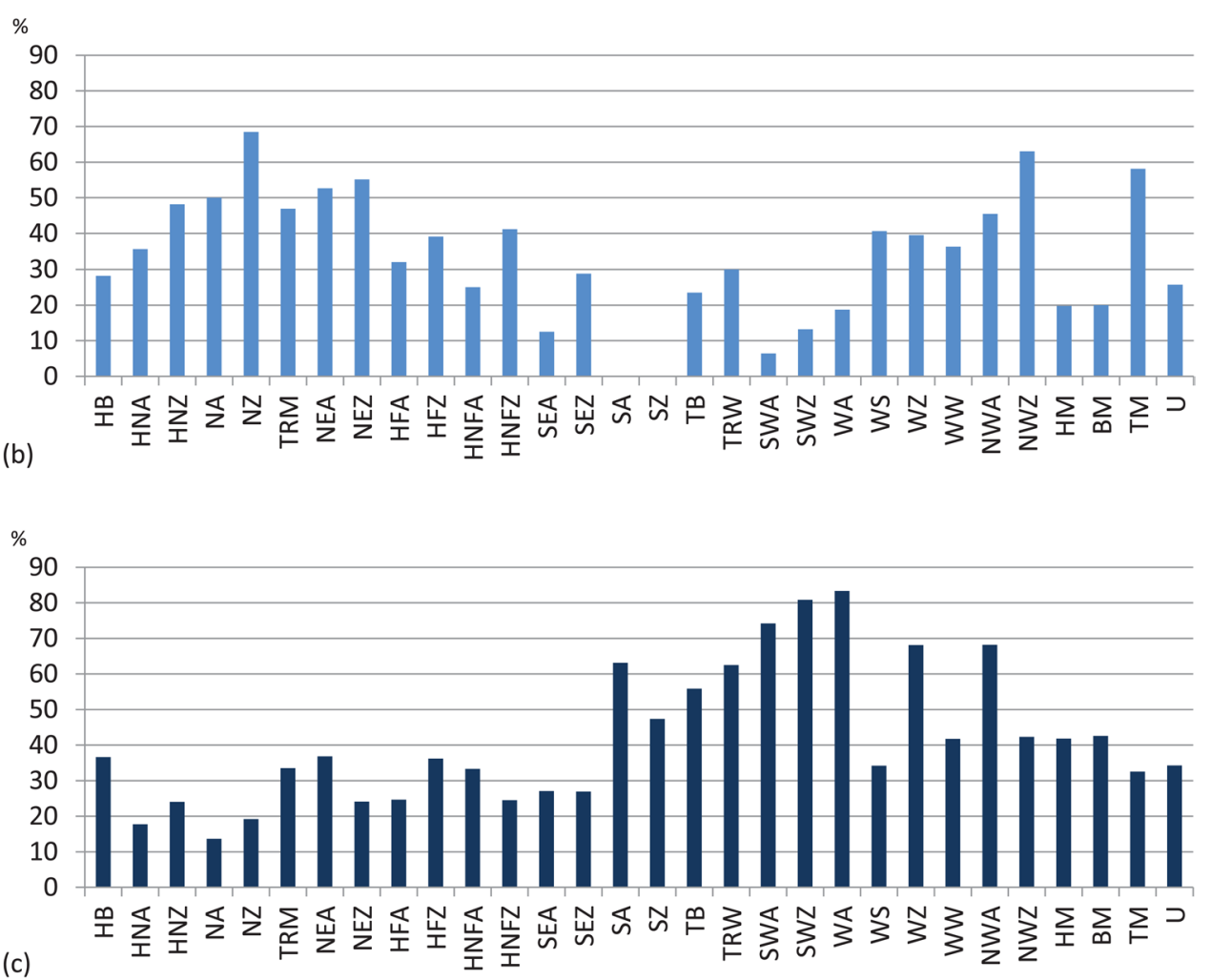

during cyclonic than anticyclonic circulation types (64.0 and $34.5 \%$ ). The westerly and northerly types especially favoured the occurrence of days with snow cover in Poznań $(28.2 \%$ each) (Table 7). The advection of the moist polar air masses causes the snowfall. 
Table 7 Frequency of the occurrence (\%) of days' number with snow cover, snow cover increase and decrease in the particular Grosswetterlagen (GWL) circulation types in the winter seasons 1966/19672019/2020 in Poznań. Explanations of the circulation types. see Table 2 and 3

\begin{tabular}{llll}
\hline Circulation type & $\begin{array}{l}\text { Number of days } \\
\text { with snow cover }\end{array}$ & $\begin{array}{l}\text { Snow cover } \\
\text { increase }\end{array}$ & $\begin{array}{l}\text { Snow cover } \\
\text { decrease }\end{array}$ \\
\hline Westerly & 28.2 & 30.2 & 37.3 \\
Northerly & 28.2 & 39.1 & 21.1 \\
Easterly & 16.2 & 14.9 & 11.2 \\
Southerly & 10.2 & 4.5 & 13.2 \\
Central & 15.6 & 10.3 & 15.8 \\
Cyclonic & 64.0 & 77.4 & 64.3 \\
Anticyclonic & 34.5 & 21.6 & 34.4 \\
Undefined & 1.5 & 1.0 & 1.3 \\
\hline
\end{tabular}

An increase in snow cover thickness was favoured by circulation types NZ and NWZ (68.5 and 63.0\%. respectively) (Fig. 9b). The increase in snow cover was not recorded during types SA and SZ at all $(0 \%)$. An increase in snow cover occurred much more frequently during cyclonic than anticyclonic circulation (77.4 and $21.6 \%$, respectively). The increase of snow cover was associated with the northerly inflow mainly (39.1\%) and next with the westerly advection (30.2\%) (Table 7). Cold and moist air inflow is the reason of snow cover thickening and permanence.

A decrease in snow cover thickness showed the highest probability during type WA (83.3\%) and SWZ (80.9\%) (Fig. 9c). The lowest chance of a decrease in snow cover thickness was determined during type NA (13.6\%) and NZ (19.2). A higher probability of a decrease in snow cover thickness was determined during cyclonic than anticyclonic circulation (64.3 and $34.4 \%$ ). Westerly types of circulation caused the decrease of snow cover $(37.3 \%)$ predominantly (Table 7). The advection of warmer air in winter favours the thaws, i.e. snow cover disappearance.

\section{Discussion of results}

Moist maritime and cold and dry continental air masses are alternating over the area of Poland during a whole cold season. Therefore, a great variability of weather conditions in winter is typical for this region. In case of dominating oceanic air, snow cover occurrence is very variable thus non-permanent phenomenon. In the multiannual period 1966/1967-2017/2020 in Poznań, seasons more abundant in snow as well as those with occasional cases of snow occurrence were determined. The number of days with snow cover is also variable in time. Season $1969 / 1970$ proved the most abundant in snow and had the highest number of days with snow cover in the studied multiannual period. Among all the seasons, that one also stood out with the highest maximum snow cover thickness and the highest winter snowiness coefficient. The mean value for that period is $19 \mathrm{~cm}$, and the number of days with snow cover is 121 . Also, the snowiness coefficient during the season 1978/1979 was very high. Winter 2019/2020 was the only snowless season in the study period. Next, the season 1988/1989 was the least snowy one. These results confirm earlier studies by Czarnecka (2012). A higher snowiness coefficient with a value of 8 for winter $1962 / 1963$ was observed in the mountainous region of Western Beskidy (Franczak 2018).

Mean total snow cover thickness in the analysed period 1966/1967-2017/2018 was $302 \mathrm{~cm}$. In particular seasons, snow cover thickness was subject to substantial changes. The highest abundance of snow $(2341 \mathrm{~cm})$ was recorded in season 1969/1970 and the lowest (only $1 \mathrm{~cm}$ ) in season 1988/1989. Summed snow cover thicknesses show that the majority of winters in Poznań do not exceed a value of $500 \mathrm{~cm}$. Simultaneously, since season 2013/2014, snow cover thickness has not exceeded $50 \mathrm{~cm}$. Poznań is located in one of the least snowy areas in Poland (Bednorz 2014), which confirms the earlier results (Falarz 2004; Nowosad and Bartoszek 2007; Czarnecka 2012; Szwed et al. 2017; Falarz and Bednorz 2021). According to the results of Niedźwiecki (1998), total snow cover thicknesses in Łódź (central Poland) were considerably higher, e.g.: in season 1978/1979, total snow cover thickness there exceeded $3500 \mathrm{~cm}$, and in season 1969/1970, it was approximately $3000 \mathrm{~cm}$. Nowosad (1994) recorded a value of almost $4500 \mathrm{~cm}$ in season 1963/1964 in Bieszczady Mountains. The year-to-year variability of the snow cover duration and its seasonal maximum depth is the largest in regions of poorest snow cover, i.e. western Poland according to Falarz and Bednorz (2021).

The percent share of days with different types of snow cover changed from season to season. Two seasons particularly stand out: 1969/1970 and 1995/1996. In the first one, exceptionally thick snow cover had a relatively high share of $9 \%$. This type was also observed often in the season 2009/2010, although in that case the share was approximately 4\%. In the season 2016/2017, a very high share of thin snow cover was observed, equalling $55 \%$. The results of Wojkowski and Partyka (2009) also show the highest share of days with thin cover in Ojców (Kraków-Częstochowa Upland). The contribution of particular types of snow cover is different in the mountain area. In winter 2005/2006 in the vicinity of Hala Jaworzyna (Silesian Beskidy), days with exceptionally thick snow cover constituted more than $80 \%$ and in the vicinity of Skrzyczne (Silesian Beskidy) more than 90\% (Kozak and Łepko 2015).

Considering the duration of particular seasons, snow in Poznań usually appears at the end of November and is observed until March, confirming earlier studies 
(Bednorz 2001, 2002). According to Czarnecka (2011), the first appearance of snow cover in Poland (in sequences of $>5$ days) is observed in the third decade of November. The month most abundant in snow in a year in the analysed period was January, with a mean multiannual snowfall of $3.5 \mathrm{~cm}$. February and December were less snowy. Thinner snow cover was recorded in April and November. Snow occasionally occurred in October and May. The study by Bednorz and Szyga-Pluta (2004) shows that Stratocumulus clouds, the strongest correlated with snow precipitation in Poznań, occur in December, January, and February, i.e. in months when the highest snow cover depth is recorded.

In lowland areas of Poland, the snow cover duration indicates an 8-year periodicity and the year-to-year variability of snow cover has been increasing, particularly during the second half of the twentieth century (Falarz 2004). Negative trends concerning days with snow cover total snow cover depth and winter snowiness coefficient in Poznań prove statistically significant according to this research. The results of Falarz and Bednorz (2021) indicate progressive negative changes of snow conditions in Poland. Several of the least snowy winters were recorded in the twenty-first century, and in the multiannual period 1960/1961-2014/2015 studied by Franczak, an evident decreasing trend referring to winter snowiness was observed. Lack of a statistically significant trend has been determined, for example, in Estonia (Jaagus 1997) and Slovakia (Lapin and Faško 2005). In lowland areas of central and northern Europe, a tendency for an increase in snow cover has been recorded (Hyvärinen 2003; Kohler et al. 2006). A further decrease in the number of days with snow cover is expected (Kjellström et al. 2011). According to Fontrodona Bach et al. (2018), extreme values of snow cover thickness decrease at a rate somewhat lower than the mean, and the contrast has become stronger over the last several decades.

The most frequent were moderately severe and moderately snowy winters. Then the mild and moderately snowy winters occurred with lower frequency. This character seems to be typical of the Polish climate. Among the obtained types, there were no two extreme types of winters: mild and snowy, and severe and low snow, but also the moderately severe and snowy winters. The results prove these reached for other areas in Poland (Paczos 1985; Janasz 2000; Majewski et al. 2011; Falarz and Bednorz 2021).

Snow cover, reflecting mutually correlated thermal and precipitation conditions, is an indicator element of changes in the climate of the winter period. In winter in urbanized areas, the effect of human activity on climatic conditions is particularly evident. Urban areas strongly affect the occurrence and strength of precipitation. An increase in the occurrence of low and trace precipitation has been observed, with a maximum in the cool season (Falarz 1998). Significant temperature changes are associated with declining snow cover, and extremely warm winters occurring most frequently in recent years proved to be also least snowy (Tomczyk et al. 2021).

A change in snow cover thickness observed from day to day and its increase or melting are related to temperature and precipitation, and these two factors are in turn dependent on atmospheric circulation (Bednorz 2001, 2002, 2004). On the basis of the conducted research, it was found that a higher probability of occurrence of snow cover was determined during cyclonic than anticyclonic circulation. The westerly and northerly types especially favoured the occurrence of days with snow cover. The increase of snow cover was associated with the northerly inflow mainly. Westerly types of circulation caused the decrease of snow cover predominantly. The westerly circulation types favour large day-to-day temperature increase (Szyga-Pluta 2021) accelerating the snow cover disappearance. Heavy snowfalls in Poznań may appear only at the condition of negative temperature anomalies, extending over most of the continent (Bednorz 2008, 2011). The highest mean annual increase in snow cover depth occurs in the case of inflow of air masses from the north-east, north, and east according to Bednorz (2001). The highest decrease in snow cover thickness occurs in the case of air masses inflow from the south-west. First snow is also related to the inflow of air masses from the north. In Poznań, abundant snowfall occurs in the case of inflow of polar-marine air masses from the northwest and arctic air masses from the east (Bednorz and SzygaPluta 2004).

The supply of solar radiation decreases in winter in Poland, and thus the atmospheric circulation becomes the most important weather shaping factor. During the time over Europe, dry and cold air masses inflowing from over the continent meet warmer and humid air masses from over the Atlantic Ocean. Baric lows and highs moving alternately with atmospheric fronts permit flow of different air masses, causing high variability of weather in central Europe (Niedźwiedź 1981). According to this study, an increase in the number of days with snow cover, as well as changes in snow cover thickness, is primarily determined by the types of cyclonic circulation. Abundant snowfall in Poznań, resulting in considerable snow accumulation, is related to negative anomalies of sea level pressure and isobaric surface $500 \mathrm{hPa}$ over the central and southern part of the continent (Bednorz 2014). Permanence of snow cover and its development are favoured by the negative NAO phase, related to the inflow of air masses from the north and considerable cooling (Gutzler and Rosen 1992; Clark et al. 1999; Bednorz 2002; Falarz 2007b, 2013). Low pressure systems, one with a centre over the Baltic Sea and the other the Mediterranean, were defined by Spreitzhofer $(1999,2000)$ as typical weather patterns related to intense snowfalls in Austria. Also, Scherrer and Appenzeller (2006) defined cyclonic activity over south-eastern Europe being one of important factors causing snowfalls in the Swiss Alps. 


\section{Conclusions}

Poznań, located in central Poland, is characterized by the low annual precipitation totals. Due to substantial importance of snow cover for thermal insulation, water availability, and river regime, a continued analysis of snow cover characteristics seems to be still necessary for the area. The observed decreasing, statistically significant trends of all winter characteristics, e.g. duration, number of days, snowiness, or severity, reflect the ongoing climate change. Trends in snow cover duration computed for the contemporary period (until 2019/2020) are stronger than these for the older periods (Falarz 2004, Szwed et. al 2017, Tomczyk et al. 2021). It leads to change in snow cover regime: a growth of frequency of mild winters shortens the period with snow cover and makes snow cover pattern more variable. The most important negative effect of occurrence of warm winters is a reduction of the duration and thickness of snow cover in the vicinity of Poznań. It has a great impact on agriculture by worsening conditions for winter crop. Earlier snow melting in spring causes ground to dry earlier and water balance deterioration. It also increases the frequency of droughts in summer.

Acknowledgements I would like to thank the anonymous reviewer for the valuable comments and suggestions to improve quality of the paper.

\section{Author contribution Not applicable.}

Data availability The data presented in this study are openly available at https://dane.imgw.pl/data/dane_pomiarowo_obserwacyjne/

Code availability Not applicable.

\section{Declarations}

Ethics approval Not applicable.

Consent to participate Not applicable.

Consent for publication Not applicable.

Competing interests The authors declare no competing interests.

Open Access This article is licensed under a Creative Commons Attribution 4.0 International License, which permits use, sharing, adaptation, distribution and reproduction in any medium or format, as long as you give appropriate credit to the original author(s) and the source, provide a link to the Creative Commons licence, and indicate if changes were made. The images or other third party material in this article are included in the article's Creative Commons licence, unless indicated otherwise in a credit line to the material. If material is not included in the article's Creative Commons licence and your intended use is not permitted by statutory regulation or exceeds the permitted use, you will need to obtain permission directly from the copyright holder. To view a copy of this licence, visit http://creativecommons.org/licenses/by/4.0/.

\section{References}

Adaptation in Europe (2013) European Environment Agency Report No 3. Denmark, Copenhagen

Armstrong RL, Brun E (eds.) (2008) Snow and climate: physical processes, surface exchange and modeling. Cambridge University Press, Cambridge, NY, pp 256. https://ui.adsabs.harvard.edu/abs/ 2008sncl.book......A

Bardossy A, Caspary HJ (1990) Detection of climate change in Europe by analyzing European atmospheric circulation patterns from 1881 to 1989. Theor Appl Climatol 42:155-167. https://doi.org/ 10.1007/BF00866871

Bartoszek K, Skiba D (2016) Circulation types classification and for hourly precipitation events in Lublin (East Poland). Open Geosci 8:214-230. https://doi.org/10.1515/geo-2016-0019

Bednorz E (2001) Snow cover and the directions of the air-flows in the North-Western Poland. Wydawnictwo Naukowe UAM. Seria Geografia 65. Poznań. pp. 131. (in Polish with English summary)

Bednorz E (2002) Snow cover in western Poland and macro scale circulation conditions. Int J Climatol 22:533-541. https://doi. org/10.1002/joc.752

Bednorz E (2004) Snow cover in eastern Europe in relation to temperature, precipitation and circulation. Int J Clim 24:591-601. https://doi.org/10.1002/joc.1014

Bednorz E (2008) Synoptic reasons for heavy snowfalls in the Polish - German lowlands. Theor Appl Climatol 92:133-140. https:// doi.org/10.1007/s00704-007-0322-4

Bednorz E (2009) Effect of pressure systems on the occurrence of snow cover in the lowlands of central Europe. Wydawnictwo Naukowe UAM Seria Geografia 82, . Poznań., p 126 (in Polish with English summary)

Bednorz E (2011) Synoptic conditions of snow cover occurrence in central European lowlands. Int J Climatol 31:1108-1118. https://doi.org/10.1002/joc. 2130

Bednorz E (2014) Synoptic study of the heaviest snowfalls in Poznan since 1960/61 to 2009/2010. Acta Climatol Chronol Univ Szeged 47-48:7-16

Bednorz E, Szyga-Pluta K (2004) Increase in snow cover depth and the occurrence of selected types of clouds in North-Western Poland. Bad Fizjogr Pol Zach Seria A 55:29-34 (in Polish with English abstract)

Brown RD, Robinson DA (2011) Northern Hemisphere spring snow cover variability and change over 1922-2010 including an assessment of uncertainty. Cryosphere 5:219-229. https://doi. org/10.5194/tc-5-219-2011

Bulygina ON, Razuvaev VN, Korshunova NN (2009) Changes in snow cover over Northern Eurasia in the last decades. Environ Res Lett 4:045026. https://doi.org/10.1088/1748-9326/4/ $4 / 045026$

Chrzanowski J (1988) Snow cover in Poland. its thickness classification and regionalization. Mater Bad Seria Meteorol 15:1-43 (in Polish with English abstract)

Clark MP, Serreze MC, Robinson AD (1999) Atmospheric controls on Eurasian snow extent. Int J Climatol 19:27-40. https:// doi.org/10.1002/(SICI)1097-0088(199901)19:1\%3c27::AIDJOC346\%3e3.0.CO;2-N

Climate Change. Impacts and Vulnerability in Europe 2012 - an indicator-based report. European Environment Agency Report no. 12 , Copenhagen.

Czarnecka M (2011) Variability of the dates of the beginning and end of snow cover of different duration time and conditions of their circulation. Prac Stud Geograf 47:109-118 (in Polish with English abstract) 
Czarnecka M (2012) Frequency of occurrence and depth of snow cover in Poland. Acta Agrophys 19(3):501-514 (in Polish with English abstract)

Falarz M (1998) Long-term variability of snow cover in Cracow and suburban areas. Acta Univ Lodz Fol Geogr Phys 3:473-481 (in Polish with English abstract)

Falarz M (2004) Variability and trends in the duration and depth of snow cover in Poland in the 20th Century. Int J Climatol 24:1713-1727. https://doi.org/10.1002/joc.1093

Falarz M (2007a) Potential period of snow cover in Poland and its changes in the 20th century. In: Piotrowicz K Twardosz R (eds) Wahania klimatu w różnych skalach przestrzennych i czasowych. Instytut Geografii i Gospodarki Przestrzennej. Uniwersytet Jagielloński, Kraków, 205-213

Falarz M (2007b) Snow cover variability in Poland in relation to the macro- and mesoscale atmospheric circulation in the 20th century. Int J Climatol 27:2069-2081. https://doi.org/10.1002/ joc. 1505

Falarz M (2013) Seasonal stability of snow cover in Poland in relation to the atmospheric circulation. Theor Appl Climatol 111(1-2):2128. https://doi.org/10.1007/s00704-012-0642-x

Falarz M, Bednorz E (2021) Snow cover change. In: Falarz M (ed) Climate change in Poland. Past, present, future. Springer Climate, Cham, 375-390. https://doi.org/10.1007/978-3-030-70328-8

Feng S, Hu Q (2007) Changes in winter snowfall/precipitation ratio in the contiguous United States. J Geophys Res Atmo 112:D15. https://doi.org/10.1029/2007JD008397

Fontrodona Bach A, van der Schrier G, Melsen LA, Klein Tank AMG, Teuling AJ (2018) Widespread and accelerated decrease of observed mean and extreme snow depth over Europe. Geophys Res Lett 45:312-319. https://doi.org/10.1029/2018GL079799

Franczak P (2018) Frequency and thickness of snow cover at the foot of the Babia Góra Massif in the winter seasons 1960/61 to 2014/15. For Res Pap 79(2):125-138. https://doi.org/10.2478/frp-20180014(inPolishwithEnglishsummary)

Gerstengarbe FW, Werner PC (2005) Katalog der Großwetterlagen Europas (1881-2004) nach Paul Hess und Helmuth Brezowsky, 6th edn. Selbstverlag des Deutschen Wetterdienstes Offenbach, , Potsdam

Gutzler DS, Rosen RD (1992) Interannual variability of wintertime snow-cover across the Northern Hemisphere. J Climate 5:14411447. https://doi.org/10.1175/1520-0442(1992)005\%3c1441: IVOWSC\%3e2.0.CO;2

Henderson GR, Leathers DJ (2010) European snow cover extent variability and associations with atmospheric forcings. Int J Climatol 30:1440-1451. https://doi.org/10.1002/joc.1990

Hess P, Brezowsky H (1977) Katalog der Grosswetterlagen Europas 1881-1976. 3. Verbesserte und ergänzte Auflage, Berichte des Deutschen Wetterdienstes 15(113)

Hyvärinen V (2003) Trends and characteristics of hydrological time series in Finland. Hydrol Res 34(1-2):71-90. https://doi.org/10. 2166/nh.2003.0029

Jaagus J (1997) The impact of climate change on the snow cover pattern in Estonia. Clim Change 36:65-77. https://doi.org/10.1023/A: 1005304720412

James PM (2007) An objective classification method for Hess and Brezowsky Grosswetterlagen over Europe. Theor Appl Climatol 88:17-42. https://doi.org/10.1007/s00704-006-0239-3

Janasz J (2000) Thermic and snow conditions of winters in Lublin (1960/61- 1994/95). Acta Agrophys 34:71-78 (in Polish with English abstract)

Kaszewski BM, Filipiuk E (2003) Variability of atmospheric circulation in Central Europe in the summer season 1881-1998 (on the basis of the Hess-Brezowsky classification). Meteorol Z 12:123130. https://doi.org/10.1127/0941-2948/2003/0012-0123
Keevallik S, Post P, Tuulik J (1999) European circulation patterns and meteorological situation in Estonia. Theor Appl Climatol 63:117127. https://doi.org/10.1007/s007040050097

Khokhlov V, Umanska O (2018) European Atmospheric Circulation Classifications. J Geogr Environ Earth Sci Int 16(3):1-8. https:// doi.org/10.9734/JGEESI/2018/41860

Kjellström E, Nikulin G, Hansson U, Strandberg G, Ullerstig A (2011) 21 st century changes in the European climate: uncertainties derived from ensemble of regional climate model simulations. Tellus A 63A:24-40. https://doi.org/10.1111/j.1600-0870.2010. 00475.x

Kohler J, Brandt O, Johansson M, Callaghan TV (2006) A long-term Arctic snow depth record from Abisko, northern Sweden, 19132004. Polar Res 25(2):91-113. https://doi.org/10.3402/polar. v25i2.6240

Kozak J, Łepko M (2015) Long-term variability of snow cover depth in Szczyrk and the surrounding region. Ecol Eng 41:153-159. https://doi.org/10.12912/23920629/1844

Kyselý J, Domonkos P (2006) Recent increase in persistence of atmospheric circulation over Europe: comparison with long-term variations since 1881. Int J Climatol 26:461-483. https://doi.org/10. 1002/joc. 1265

Lapin M, Faško P (2005) Snow cover changes in the Little Carpathians in Slovakia. Croat Meteorol J 40:658-661. https://hrcak. srce.hr/64925

Majewski G, Gołaszewski D, Przewoźniczuk W, Rozbicki T (2011) Thermal and snow conditions in Warsaw 1978/79-2009/10. Prac Stud Geogr 47:147-155 (in Polish with English abstract)

Mezghani A, Parding KM, Dobler A, Benestad RE, Haugen JE, Piniewski M (2017) Projections of changes in temperature, precipitation and snow cover. In: Kundzewicz Z, Hov $\varnothing$, Okruszko T (eds) Zmiany klimatu i ich wpływ na wybrane sektory w Polsce. Poznań, Poland, pp 119-129 (in Polish)

Niedźwiecki M (1998) The characteristic of snow cover in Łódź in the period 1950-1989. Acta Univ Lodz Fol Geogr Phys 3:265277 (in Polish with English summary)

Niedźwiedź T (1981) Synoptic situations and their impact on the spatial differentiation of selected climate elements in the upper Vistula basin. Rozprawy Habilitacyjne Uniwersytetu Jagiellońskiego 56, pp. 166. (in Polish with English summary)

Nowosad M (1994) A draft of the characteristics of snow cover in the Bieszczady Mountains. Ann Univ Marie Curie-Sk łodowska Sect B XLIX:197215 (in Polish with English summary)

Nowosad M, Bartoszek K (2007) Long-term variability of snow cover depth in Lublin and the surrounding region. In: Twardosz R (ed) Piotrowicz K. Wahania klimatu w różnych skalach przestrzennych i czasowych. Instytut Geografii i Gospodarki Przestrzennej. Uniwersytet Jagielloński, Kraków, pp 411-421 (in Polish with English summary)

Paczos S (1982) Thermal and snow relations in Poland. Rozpr Habilit Uniw Marii Curie-Sk łodowskiej 24:180 (in Polish)

Paczos S (1985) The problem of winter classification in the light of various thermal criteria. Ann UMCS 40(7):133-155 (in Polish)

Piotrowski P, Jędruszkiewicz J (2013) Projections of thermal conditions for Poland for winters 2012-2050 in relations to atmospheric circulation. Meteorol Z 22(5):569-575. https://doi.org/ 10.1127/0941-2948/2013/0450

Salmi T, Maiittii A, Anttila P, Ruoho-Airola T, Amnel T (2002) Detecting trends of annual values of atmospheric pollutants by the Mann-Kendall test and Sen's slope estimates-the excel template application MAKESENS, vol 31. Publications on air quality. Finnish Meteorological Institute, Helsinki, pp 1-35

Scherrer S, Appenzeller C (2006) Swiss alpine snow pack variability: major patterns and links to local climate and large-scale flow. Climate Res 32:187-199. https://doi.org/10.3354/cr032187 
Spreitzhofer G (1999) Spatial, temporal and intensity characteristics of heavy snowfall events over Austria. Theor Appl Climatol 62:209-219. https://doi.org/10.1007/s00704005008

Spreitzhofer G (2000) On the characteristics of heavy multiple day snowfalls in the Eastern Alps. Nat Hazards 21:35-53. https:// doi.org/10.1023/A:1008149104912

Szwed M, Pińskwar I, Kundzewicz ZW, Graczyk D, Mezghani A (2017) Changes of snow cover in Poland. Acta Geophys 65:6576. https://doi.org/10.1007/s11600-017-0007-z

Szyga-Pluta K (2021) Large day-to-day variability of extreme air temperatures in Poland and its dependency on atmospheric circulation. Atmosphere 12:80. https://doi.org/10.3390/atmos12010080

Tomczyk AM, Bednorz E, Szyga-Pluta K (2021) Changes in air temperature and snow cover in winter in Poland. Atmosphere 12:68. https://doi.org/10.3390/atmos 12010068

Tomczyk AM, Szyga-Pluta K, Majkowska A (2015) Frost and frostfree periods in Poland and neighboring countries. Open Geosci 7:812-823. https://doi.org/10.1515/geo-2015-0061
Ustrnul Z (2006) Spatial differentiation of air temperature in Poland using circulation types and GIS. Int J Climatol 26:1529-1546. https://doi.org/10.1002/joc.1393

Ustrnul Z, Wypych A, Winkler JA, Czekierda D (2014) Late spring freezes in Poland in relation to atmospheric circulation. Quaestiones Geographicae 33(3):165-172. https://doi.org/10.2478/ quageo-2014-0039

Wojkowski J, Partyka J (2009) Nival conditions in Ojców. Prądnik. Prace i Materiały Muzeum im. Prof Władysława Szafera 19:75-88 (in Polish with English summary)

Ye K, Lau NC (2017) Influences of surface air temperature and atmospheric circulation on winter snow cover variability over Europe. Int J Climatol 37:2606-2619. https://doi.org/10.1002/joc.4868

Publisher's note Springer Nature remains neutral with regard to jurisdictional claims in published maps and institutional affiliations. 